\title{
RELATO DE CASO: O PROCESSO DE IMPLANTAÇÃO DO CARGO DE ENFERMEIRO SÊNIOR NA UNIDADE DE INTERNAÇÃO EM UM HOSPITAL ONCOLÓGICO DE SÃO PAULO
}

LIMA, Natalia Brito de; HERENY, Adriana Aguirra de Freitas; BARBOSA, Adriana Santos; DANTAS, Mainara Honorato; SCHUNCK, Juliana.

\section{INTRODUÇÃO E OBJETIVO}

A complexidade da assistência ao paciente oncológico exige do enfermeiro assistencial um cuidado qualificado e especializado. Diante deste cenário, observou-se a necessidade de surgir um cargo que atuasse em sinergia com os enfermeiros assistenciais, agregando a função de ligação entre os objetivos organizacionais e as demandas assistenciais. Sendo assim configurado o cargo de enfermeiro sênior.

\section{MATERIAL E MÉTODOS}

Esse cargo foi desenhado para ser ocupado por profissionais engajados com a missão e valores da instituição, que tenham consolidadas as rotinas e políticas institucionais, com perfil de liderança, e bom desenvolvimento em gestão de pessoas. Após processo seletivo e esclarecimento do escopo, foram definidas metas para desenvolvimento profissional e metas institucionais.

\section{RESULTADOS E DISCUSSÃO}

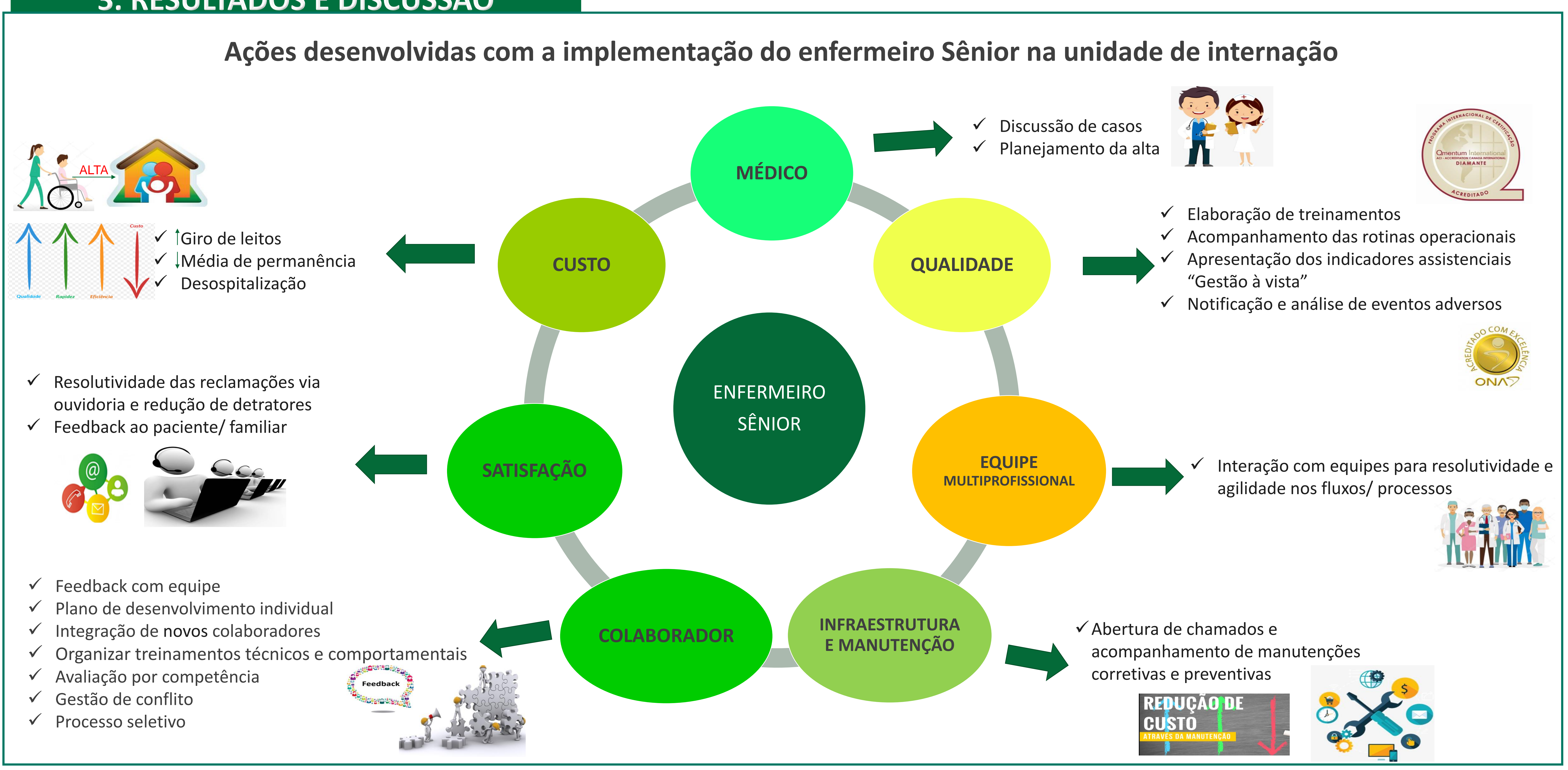

\section{CONCLUSÃO}

A implantação do cargo de enfermeiros seniores nas unidades, atuando na otimização dos processos e no desenvolvimento das equipes, contribuiu significativamente na melhoria dos indicadores assistenciais e institucionais. 